\title{
Harmonisasi Kewenangan Pembuatan Risalah Lelang Antara Notaris Dengan Pejabat Lelang
}

\author{
Ni Made Ayu Sintya Dewi', Made Gde Subha Karma Resen²
}

${ }^{1}$ Magister (S2) Kenotariatan Universitas Udayana, E-mail: ayusintyad23@gmail.com

${ }^{2}$ Fakultas Hukum Universitas Udayana, Email: karma_resen@unud.ac.id

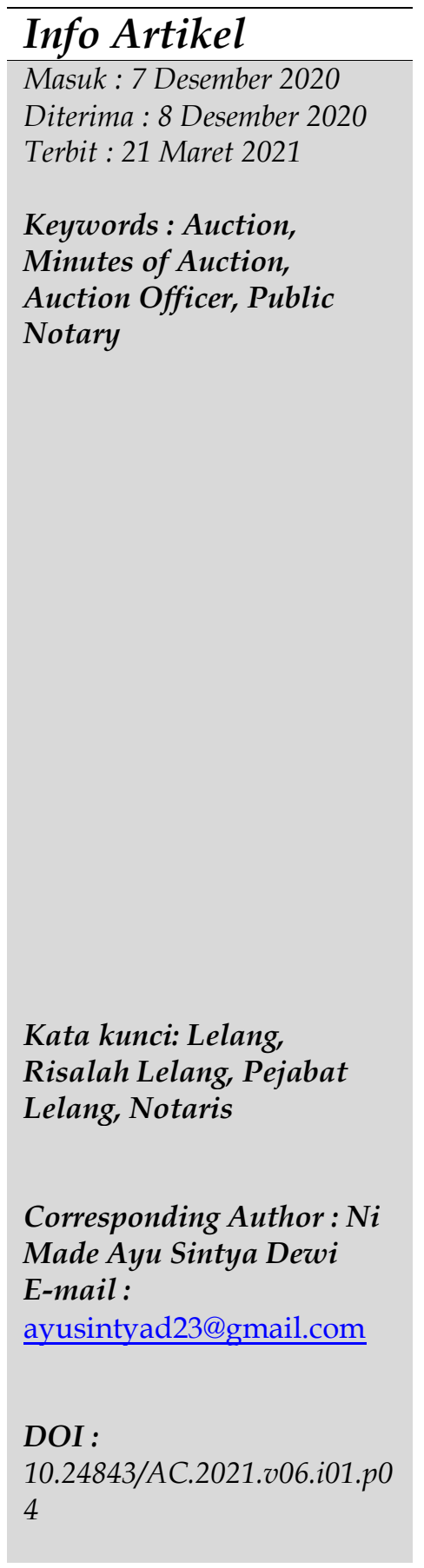

\begin{abstract}
This journal's purpose is to understand the harmonization of authority arrangements for making auction minutes and to find out the evidentiary strength of auction minutes. This research uses normative legal research with an approach to the concept of law and legislation. Based on the lex special derogate legi generale principle, the authority to prepare auction minutes is based on Staatsblad No. 189 which was promulgated in 1908 concerning Vendu Reglement / VR (hereinafter referred to as Tender Regulations) which regulate the authority to make Minutes of Auction rests with the Auction Officer not the Notary Public. Although a Notary Public can be appointed as Class II Auction Officer according to Article 7 the Vendue Intructie in Indonesian is called an auction instruction Jo. Regulation of the Minister of Finance of the Republic of Indonesia Number 175 / PMK.06 / 2010 concerning Class II Auction Officers (hereinafter referred to as PMK Class II Auction Officers), however this authority is given the capacity of a Notary as Class II Auction Officer and not the capacity as a Notary. The power of proof of the auction minutes according to Article 1868 of the Criminal Code, the minutes of auction fulfilling the three elements of the deed must be made by a General Official, the deed is determined by law and the General Official who makes it must be authorized to make the deed so that it is said that the Minutes of Auction are authentic deeds having the power of proof that perfect.
\end{abstract}

\begin{tabular}{l} 
Abstrak \\
\hline Tujuan jurnal ini yaitu untuk memahmi harmonisasi \\
pengaturan kewenangan Pembuatan Risalah Lelang dan untuk \\
mengetahui kekuatan pembuktian risalah lelang. Penelitian ini \\
menggunakan penelitian hukum normatif dengan pendekatan \\
konsep hukum dan perundang-undangan. Berdasarkan asas lex \\
special derogate legi generale pengaturan kewenangan \\
Pembuatan Risalah Lelang adalah berdasarkan Staatsblad No. \\
189 yang diundangkan pada tahun 1908 tentang Vendu \\
Reglement/VR (selanjutnya disebut Peraturan Lelang) yang \\
mengatur kewenangan membuat Risalah Lelang terdapat pada \\
Pejabat Lelang bukan pada Notaris. Walaupun Notaris dapat \\
diangkat sebagai Pejabat Lelang Kelas II menurut Pasal 7 \\
Vendue Intructie dalam bahasa Indonesia disebut Intruksi lelang \\
Jo. Peraturan Menteri Keuangan Republik Indonesia Nomor \\
175/PMK.06/2010 tentang Pejabat Lelang Kelas II (selanjutnya
\end{tabular}


disebut PMK Pejabat Lelang Kelas II), namun wewenang itu diberikan kapasitas Notaris sebagai Pejabat Lelang Kelas II dan bukan kapasitasnya sebagai Notaris. Kekuatan pembuktian risalah lelang menurut Pasal 1868 KUHPer, Risalah lelang memenuhi ketiga unsur akta itu harus dibuat seorang Pejabat Umum, akta itu ditentukan oleh undang-undang dan Pejabat Umum yang membuat harus berwenang membuat akta tersebut sehingga dikatakan Risalah Lelang merupakan akta otentik memiliki kekuatan pembuktian yang sempurna.

\section{Pendahuluan}

Lelang merupakan kegiatan untuk menjual barang yang dilaksanakan dengan cara terbuka untuk umum dengan tawar menawar yang dilakukan secara tertulis dan dapat juga secara lisan dengan proyeksi meningkat untuk mencapai harga tertinggi yang harus dilakukan pengumuman lelang sebelumnya dan penawaran tertinggi merupakan pemenang lelangnya dan berhak memiliki barang tersebut. ${ }^{1}$ Sejarah lelang di Indonesia diawali tahun 1908 yaitu tepatnya pada jaman pemerintahan Hindia Belanda. Pada tahun 1908 pemerintah Hindia Belanda mengundangkan Staatsblad No. 189 yang diundangkan pada tahun 1908 tentang Vendu Reglement/VR (selanjutnya disebut Peraturan Lelang) tujuan di undangkannya peraturan tersebut guna untuk menanggulangi permasalahan mengenai penjualan barang-barang pejabat di pemerintahan Hindia Belanda yang dijabat oleh orang belanda yang pada saat itu terkena mutasi serta barang-barang bekas perusahaan Belanda.

Peraturan Lelang pun juga menjadi peraturan awal tentang lelang di Indonesia, dikenal dengan nama Peraturan Lelang, peraturan ini merupakan Ordonansi/diadaptasi pada tanggal 28 Pebruari 1908 dan berlaku sejak 1 April 1908 (selanjutnya disebut Peraturan Lelang). Lelang pada prinsipnya merupakan konsep pada bidang keuangan dan ekonomi di Indonesia, keuntungan kegiatan lelang didasari oleh jenis-jenis barang yang dilelang biasanya variatif dan dalam jumlah yang banyak, sehingga dapat memilih lebih leluasa, kemudian sering kali barang-barang pada pelelangan dijual dengan harga yang lebih murah dari harga pasaran dan barang akan cepat laku bila melalui mekanisme lelang. ${ }^{2}$

Pejabat lelang wajib melaporkan hasil lelang dalam sebuah suatu risalah lelang sebagaimana yang ditentukan pada Pasal 35 Peraturan Lelang di Indonesia. Risalah Lelang adalah catatan atau berita acara dalam bentuk akta otentik. Peraturan Lelang hingga memiliki peraturan pelaksana dan yang terbaru yang sudah beberapa kali diganti dan dirubah yaitu Peraturan Menkeu RI No. 27/PMK.06/2016 Tentang Petunjuk Pelaksana Lelang (untuk seterusnya dapat disingkat menjadi PMK Pelaksana Lelang), peraturan menentukan kewajiban seorang pejabat lelang untuk membuat

${ }^{1}$ Faisal, M. (2014). “Upaya Perlindungan Hukum Pemenang Lelang Sebagai Pembeli Beritikad Baik Terhadap Putusan Re-Eksekusi". Jurnal Hukum \& Pembangunan. 44(1). 83-101. p. 90.

2 Haris, M. (2018). “Kewenangan Notaris sebagai Pejabat Lelang Kelas II dalam Memberikan Penyuluhan Hukum atas Akta Risalah Lelang yang Dibuatnya". Syariah: Jurnal Hukum dan Pemikiran, 17(1). 53-63. p. 56 
laporan berupa risalah lelang apabila melakukan kegiatan lelang, seperti yang dimuat pada Pasal 85 ayat (1). Kemudian pada tahun 2014 diundangkan Undang-Undang No. 2 Tahun 2014 Tentang Jabatan Notaris (selanjutnya disebut UUJN) yang mengakibatkan terjadinya suatu konflik norma dengan Peraturan Lelang, karena Pasal 15 ayat (2) huruf g merumuskan jikalau seorang Notaris memiliki kewenangan untuk membuat risalah lelang. Konflik norma terdapat pada Pasal 85 ayat (1) PMK Pelaksana Lelang dan pada Pasal 15 ayat (2) UUJN institusi yang ditunjuk oleh peraturan masing-masing yang berbeda, Peraturan lelang menunjuk Peraturan lelang menunjuk Pejabat lelang yang mempunya kewenangan untuk membuat akta risalah lelang, sedangkan pada UUJN yang mempunyai kewenangan membuat akta risalah lelang adalah notaris.

Timbulnya konflik norma berimplikasi terjadi kondisi tidak terciptanya kepastian hukum, terhadap bidang pelelangan, khususnya dalam kewenangan untuk membuat risalah lelang, apakah menjadi tanggungjawab dan wewenang pejabat lelang atau akan menjadi tanggungjawab dan wewenang notaris. Konflik norma ini akan berakibat pada tataran praktis di lapangan dalam membuat risalah lelang tersebut, sehingga penting untuk dikaji secara lebih mendalam dan komprehensif guna menemukan suatu analisa dalam bentuk jurnal ilmiah dengan judul "Harmonisasi Kewenangan Pembuatan Risalah Lelang Antara Notaris Dengan Pejabat Lelang".

Dipaparkannya latar belakang masalah guna untuk mengetahui apa yang menjadi dasar permasalahan sehingga dapat diambil 2 (dua) rumusan masalah dalam jurnal ilmiah ini antara lain mengenai :

1) Bagaimana harmonisasi pengaturan kewenangan Pembuatan Risalah Lelang ?

2) Bagaimana kekuatan pembuktian risalah lelang

Suatu jurnal ilmiah haruslah memiliki tujuan yang hendak dicapai agar apa yang ditulis memiliki nilai kegunaan, sehingga tujuan penulisan yang terdiri dari tujuan penulisan umum dan tujuan penulisan khusus. Tujuan umum daripada penulisan jurnal ilmiah ini diharapkan pembaca baik itu mahasiswa, dosen, notaris maupun masyarakat umum memahami tentang harmonisasi kewenangan pembuatan risalah lelang antara notaris dengan pejabat lelang, kemudian tujuan khususnya yaitu untuk mengetahui harmonisasi pengaturan kewenangan Pembuatan Risalah Lelang dan untuk mengetahui kekuatan pembuktian risalah lelang.

Penyusunan jurnal ilmiah mengenai risalah lelang ini memiliki nilai pembaharuan untuk dunia pendidikan ilmu hukum kenotariatan, walaupun pada masa yang lampau sudah ada membahas tentang risalah lelang, namun ada nilai pembeda yang terdapat pada tulisan ini dibandingkan tulisan terdahulu. Adapun tulisan terdahulu yang membahas mengenai risalah lelang yaitu:

1) Jurnal ilmiah yang dibuat oleh Mohamad Erik, dkk., jurnal dengan judul "Karateristik Akta Risalah Lelang Sebagai Akta Otentik", jurnal yang terbit pada Jurnal Hukum Jatiswara Fakultas Hukum Universitas Mataram, Volume 33, Nomor 2, Bulan Juli Tahun 2018. Permasalahan yang dibahas yaitu 
mengenai "Kedudukan Akta Risalah Lelang sebagai akta otentik dan Kekuatan Pembuktian Pada Akta Risalah Lelang Sebagai akta otentik."3

2) Jurnal ilmiah yang dibuat oleh Tomy Indra Sasongko, jurnal dengan judul "Kewenangan Notaris Dalam Pembuatan Akta Risalah Lelang Pasca Berlakunya Peraturan Menteri Keuangan Nomor 90/PMK.06/2016 Tentang Pedoman Pelaksanaan Lelang Dengan Penawaran Secara Tertulis Tanpa Kehadiran Peserta Lelang Melaui Internet", yang terbit pada Jurnal Lex Renaissance Fakultas Hukum Universitas Islam Indonesia, Volume 3, Nomor 1, Bulan Januari Tahun 2018. Permasalahan yang dibahas mengenai "pelaksanaan wewenang dan tanggungjawab notaris dalam pelaksanaan lelang sebagai pejabat lelang kelas II dan pelaksanaan lelang melalui internet yang dilaksanakan oleh Kementerian Keuangan Republik Indonesia Direktorat Jenderal Kekayaan Negara di Indonesia." 4

Berdasarkan pembandingan dengan 2 (dua) jurnal ilmiah terdahulu atau sebelumnya, tulisan pada jurnal ilmiah ini memiliki nilai pembaharuan dan orisinil. Jurnal ini berjudul "Harmonisasi Kewenangan Pembuatan Risalah Lelang Antara Notaris Dengan Pejabat Lelang". Pembaharuan pada jurnal ilmiah ini yaitu mengangkat permasalahan mengenai harmonisasi pengaturan kewenangan Pembuatan Risalah Lelang dan kekuatan pembuktian risalah lelang.

\section{Metode Penelitian}

Metode Penelitian merupakan langkah-langkah dilakukan dengan terukur dan terencana yang memuat kontruksi dan analisa objek yang hendak diteliti dengan cara yang konsisten. ${ }^{5}$ Penelitian hukum normatif yang digunakan pada tulisan ini bermakna bahwa tulisan ini diteliti dengan cara menganalisa secara sistematis suatu peraturan dengan peraturan lainya atau dengan aturan diatas dan dibawahnya, maupun aturan yang sederajat hierarkinya. ${ }^{6}$ Terkait dengan penelitian hukum normatif, pada penelitian jurnal ini UUJN bertentangan dengan Peraturan Lelang yang memiliki kedudukan atau derajat yang sama terkait dengan wewenang membuat risalah lelang.

Penelitian pada jurnal ini memakai pendekatan konsep hukum dan pendekatan perundang-undangan. ${ }^{7}$ Jadi isu hukum dikaji dengan peraturan perundang-undangan yang terkait antara lain UUJN dan Peraturan Lelang, kemudian isu hukum yang ada menggunakan konsep hukum yang umum pada keilmuan ilmu hukum yaitu

\footnotetext{
${ }^{3}$ Erik. M. dan Triyanti. (2019). Karakteristik Akta Otentik Pada Akta Risalah Lelang. Jurnal Hukum Jatiswara. 33(2). 1-20. p. 11

${ }^{4}$ Sasongko, T. I. (2018). Kewenangan Notaris Dalam Pembuatan Akta Risalah Lelang Pasca Berlakunya Peraturan Menteri Keuangan Nomor 90/PMK. 06/2016 Tentang Pedoman Pelaksanaan Lelang Dengan Penawaran Secara Tertulis Tanpa Kehadiran Peserta Lelang Melaui Internet. Lex Renaissance, 3(1), 206225. p. 207

5 Soerjono Soekanto, (2012), Pengantar Penelitian Hukum, Jakarta, Universitas Indonesia Press, h.42

${ }^{6}$ Jody Bagus, W. I. W. (2019). “Tinjauan Yuridis Terkait Pendaftaran Hak Tanggungan Secara Elektronik". Jurnal Acta Comitas : Jurnal Hukum Kenotariatan. 5(1). 79-88. p. 82.

7 Kusumaningrat, I. D. G. A. "Perlindungan Hukum Bagi Kreditor Terhadap Hapusnya Hak Atas Tanah yang Dibebani Hak Tanggungan". Acta Comitas: Jurnal Hukum Kenotariatan, 4(2), 251-260. p. 225
} 
menggunakan asas preferensi hukum dan menggunakan teori kewenangan yang dikemukakan oleh ahli-ahli hukum yang diperoleh dan bersumber dari buku-buku hukum dan jurnal ilmiah yang telah terbit dalam berbagai jurnal yang ada di Indonesia maupun dunia serta sumber-sumber yang relevan lainya guna untuk menyelesaikan permasalahan yang ada. ${ }^{8}$ Teknik deskipsi digunakan untuk menganalisis bahan hukum yang digunakan dalam penulisan jurnal ini, teknik deskripsi berarti menguraikan apa adanya terhadap suatu kondisi atau posisi dari prosisi-prosisi hukum.

\section{Hasil dan Pembahasan}

\subsection{Harmonisasi Pengaturan Kewenangan Pembuatan Risalah Lelang}

Lelang menurut Tomy Indra S. pada jurnal yang ditulisnya menyebutkan bahwa Lelang merupakan kegiatan jual beli barang dengan pengumuman dan penawaran di buka secara umum terkait dengan objek yang dijual tersebut kepada para peserta lelang disaat yang serentak. ${ }^{9}$ Sedangkan Lelang menurut Satrya Haprabu dalam jurnalnya adalah penjuaan barang yang terbuka untuk umum dengan penawaran harga secara tertulis maupun lisan yang semakin meningkat atau menurun untuk mencapai harga tertinggi yang didahului dengan pengumuman lelang. ${ }^{10}$ Pendapat ini sejalan dengan pengertian lelang yang ditentukan dalam Pasal 1 angka 1 PMK Pelaksanaan Lelang yang merupakan peraturan pelaksana daripada Peraturan Lelang. Lelang dilaksanakan dengan melakukan tawar menawar harga dengan sesama peserta lelang guna mendapatkan harga yang terbaik daripada objek lelang tersebut, sehingga apabila telah tercapai harga yang tidak ada lagi peserta lelang yang menawarnya dengan harga yang lebih tinggi, maka peserta tersebut akan menjadi pemenang lelang dan berhak untuk mendapatkan objek atas lelang tersebut dan pemenang lelang tersebutlah yang berhak menjadi pembeli. ${ }^{11}$ Lelang pun menurut Pasal 2 peraturan tersebut haruslah dilakukan dihadapan pejabat lelang sepanjang Undang-Undang tidak menentukan lain. Artinya apabila tidak ditentukan secara khusus dalam Undang-Undang maka setiap lelang harus dilakukan dihadapan pejabat lelang.

Bukti telah dilaksanakanya proses lelang, pada produk akhir seorang pejabat lelang wajib membuat suatu yang disebut risalah lelang. ${ }^{12}$ Kewajiban ini ditentukan pada Pasal 35 Peraturan Lelang bahwa:

“seorang pejabat lelang wajib membuat berita acara lelang, istilah berita acara lelang ini lah yang disebut dewasa kini menjadi risalah lelang, ini menjadi suatu

\footnotetext{
8 Sonbai, A. I. K. (2019). "Kebijakan Formulasi Pertanggungjawaban Pidana Pengguna Jasa Prostitusi Melalui Media Online". Acta Comitas: Jurnal Hukum Kenotariatan, 4(2), 271-282. p. 276

9 Sasongko, T. I. (2018). "Kewenangan Notaris Dalam Pembuatan Akta Risalah Lelang Pasca Berlakunya Peraturan Menteri Keuangan Nomor 90/PMK. 06/2016 Tentang Pedoman Pelaksanaan Lelang Dengan Penawaran Secara Tertulis Tanpa Kehadiran Peserta Lelang Melaui Internet". Lex Renaissance, 3(1), 206-225. p. 207

10 Satrya, H. (2017) "Penjualan Lelang Barang Jaminan Hak Tanggungan Menurut Perspektif Hukum Islam." Jurnal Repertorium IV (1) 52-60

${ }^{11}$ Ibid.

12 Marziah, A., Rahayu, S. W., \& Jauhari, I. (2019). “Pembuktian Risalah Lelang Bagi Pemenang Eksekusi Hak Tanggungan". Jurnal IUS Kajian Hukum dan Keadilan, 7(2), 225-236. p. 232
} 
landasan autentifikasi perjalalan dan proses serta hasil lelang, berita acara lelang berisikan semua aktifitas serta peristiwa yang terjadi pada lelang".13

Muhamad Erik menjelaskan pada Jurnalnya bahwa Risalah lelang setidaknya harus berisikan dan menjelaskan apa saja yang menjadi objek lelang, menjelaskan mengapa sampai lelang itu diadakan, menjelaskan dimana lelang tersebut dilakukan beserta waktu pelaksanaan lelang, bagaimana jalan atau proses lelang itu berjalan lengkap dengan proses tawar menawar sampai akhirnya mendapatkan pemenang lelang yang berhak atas objek lelang tersebut dan siapa saja yang mengikuti lelang tersebut meliputi penjual atau pemohon lelang, siapa saja yang melakukan penawaranpenawaran , dan siapa pemenang lelang. ${ }^{14}$

Peraturan Lelang yang lahir pada tahun 1908 dan telah dirubah beberapa kali sampai yang terakhir pada tahun 1941 ini merupakan peraturan khusus yang kedeudukannya sejajar dengan undang-undang yang berlaku saat ini dan mengatur mengenai lelang di Indonesia, peraturan lelang ini memiliki peraturan pelaksana yaitu PMK Pelaksanaan Lelang yang dikeluarkan oleh menteri keuangan Republik Indonesia, yang mengatur pada prinsipnya pejabat lelang memiliki wewenang membuat suatu risalah lelang. Kemudian pada tahun 2014 munculah UUJN yang juga turut mengatur menurut mengenai kewenangan membuat risalahlelang yaitu pada Pasal 15 ayat (2) hurug g menentukan pada intinya bahwa "seorang notaris juga diberikan kewenangan dalam hal membuat risalah lelang. Peraturan Lelang dan UUJN sama sama mengatur tentang kewenangan untuk membuat risalah lelang, yang secara normatif yang berwenang membuat risalah lelang ialah Pejabat Lelang yang wewenangnya diberikan dengan Peraturan Lelang dan Notaris yang wewenang nya diberikan oleh UUJN." Antara Peraturan Lelang dan UUJN terjadi suatu konflik norma atau disebut dengan conflict of norm atau lebih mudah disebut pertentangan norma, karena 2 peraturan dengan kedudukan yang sama sebagai suatu Undang-Undang mengatur hal yang berbeda, pertentangan norma ini akan mengakibatkan terjadinya ketidak pastian hukum terhadap siapa yang berwenang untuk membuat akta risalah lelang dan bagaimana mengenai kekuatan hukum produk risalah lelang tersebut.

Permasalah pertentangan norma yang terjadi dapat diselesaikan menggunakan asasasas hukum yang relevan dan sudah digunakan diseluruh dunia yaitu asas preferensi hukum, terdiri dari 3 asas yang meliputi asas lex superior, asas lex spesialis, dan asas posterior. ${ }^{15}$ "a) Asas lex superior derogate lex inferior bermakna bahwa perundangundangan yang derajatnya lebih rendah dikesampingkan oleh perundang-undangan yang derajatnya lebih tinggi, b) Asas lex posteriori derogate lex priori bermakna peraturan perundang-undangan yang lama dikesampingkan oleh peraturan perundangundangan yang lebih baru, c) Asas lex specialis derogate legi generale yang bermakna dua peraturan perundang-undangan yang secara hierarkis mempunyai kedudukan yang sama. Akan tetapi ruang lingkup materi muatan antara kedua peraturan peundangundangan itu tidak sama, yaitu yang satu merupakan pengaturan secara khusus dari

\footnotetext{
${ }^{13}$ Harahap, M. Y. (2007). Ruang Lingkup Permasalahan Eksekusi Bidang Perdata, cet. 3., h. 187

${ }^{14}$ Erik, M., Triyanto, T., \& Sesung, R. (2018). "Karakteristik Akta Otentik Pada Akta Risalah Lelang". Jatiswara, 33(2). 1-20 . p. 11

${ }^{15}$ Hadjon, P. M., \& Djamiati, T. S. (2014). Argumentasi hukum. Gadjah Mada University Press, h. 31
} 
yang lain."16 Dari ketiga asas preferensi hukum yang ada yang paling cocok dengan permasalahan adalah dengan menyelesaikanya dengan Asas lex specialis derogate legi generale bahwa peraturan yang lebih umum dikesampingkan dengan peraturan yang lebih khusus.

Berdasarkan asas lex specialis derogate legi generale maka yang digunakan adalah Peraturan Lelang, bukan UUJN, karena kekhususannya tentang lelang, Jadi yang berwenang menjadi pembuat risalah lelang berdasakan kewenangan untuk membuat risalah lelang yang diperoleh dari Peraturan Lelang menurut Teori Kewenangan yang membahas mengenai sumber sumber kewenangan, yaitu kewenangan atribusi, delegasi, dan mandat, kewenangan atribusi menunjuk pada kewenangan yang asli atas dasar konstitusi di dalam Undang-Undang, kewenangan delegasi, haruslah ditegaskan suatu pelimpahan wewenang kepada organ pemerintahan yang lain. Pada mandat tidak terjadi pelimpahan apapun dalam arti pemberian wewenang, akan tetapi, yang diberi mandat bertindak atas nama pemberi mandat. ${ }^{17}$ Sesuai dengan Teori Kewenangan atribusi, tanggungjawab dan wewenang membuat risalah lelang adalah Pejabat Lelang.

Kewenangan Notaris dalam hal membuat risalah lelang harus dihilangkan dari UUJN, karena membuat risalah lelang bukan kewenangan Notaris. Walaupun benar Notaris dapat diangkat menjadi pejabat lelang kelas II yang diatur pada Pasal 7 Vendue Intructie atau dalam bahasa Indonesia disebut Intruksi lelang Jo. Pasal 17 ayat (2) Peraturan Menteri Keuangan Republik Indonesia Nomor 175/PMK.06/2010 tentang Pejabat Lelang Kelas II (selanjutnya disebut PMK Pejabat Lelang Kelas II), yang pada prinsipnya seorang Notaris dapat diangkat menjadi Pejabat Lelang Kelas II. Seorang notaris dalam melaksanakan tugasnya sebagai Pejabat Lelang Kelas II haruslah dipisahkan dari profesi Notarisnya, karena jabatan notaris dengan jabatan pejabat lelang harus dibedakan. Sehingga tidak semua notaris dapat melakukan wewenang dalam pembuatan Risalah Lelang, hanya seorang Notaris yang secara sah telah berstatus atau diangkat untuk menjadi Pejabat Lelang Kelas II oleh Menteri Keuangan yang dapat membuat risalah lelang yang berpedoman pada Peraturan Lelang dan Intruksi Lelang dan peraturan pelaksanaan dibawahnya seperti PMK Pelaksanaan Lelang dan PMK Pejabat Lelang Kelas II, bukan berpedoman pada UUJN.

Oleh karena itu harmonisasi pengaturan kewenangan Pembuatan Risalah Lelang berdasarkan asas lex specialist derogate legi generalist yang digunakan adalah "Peraturan Lelang sebagai dasar kewenangan membuat Risalah Lelang yaitu terdapat pada Pejabat Lelang bukan pada Notaris. Walaupun Notaris dapat diangkat sebagai Pejabat Lelang Kelas II menurut Pasal 7 Intruksi Lelang jo. PMK Pejabat Lelang Kelas II, namun wewenang itu diberikan dalam kapasitas Notaris sebagai Pejabat Lelang Kelas II yang telah diangkat oleh Menteri Keuangan dan bukan kapasitasnya sebagai Notaris."

\subsection{Kekuatan Pembuktian Risalah Lelang}

\footnotetext{
${ }^{16}$ Marzuki, M. (2017). Penelitian Hukum: Edisi Revisi. Prenada Media., h. 101

17 Rafly R. P., Johny L., \& Neni K. (2018) "Kewenangan Pemerintah Desa Dalam Peningkatan Perekonomian Di Desa Mahangiang Kecamatan Tagulandang Kabupatenkepulauan Sitaro." Eksekutif Jurnal Jurusan Ilmu Pengetahuan1, (1) 1-10
} 
Berbicara mengenai kekuatan pembuktian, harus terlebih dahulu mengetahui apa itu pembuktian, pembuktian merupakan serangkaian proses guna memperoleh atau mengadili suatu hak sehingga tujuan atas nilai kepastian dan keadilan dalam hukum dapat tercapai. ${ }^{18}$ Mengenai kekuatan pembuktian suatu risalah lelang, tidak bisa lepas dari derajat suatu risalah lelang itu sendiri. Menurut hukum perdata derajat pembuktian terbagi atas 2 jenis yaitu Akta otentik dan Surat di bawah tangan sebagaimana diatur Pasal 1867 KUHPer. Akta otentik menurut Pasal 1870 KUHPer "memiliki kekuatan hukum pembuktian yang sempurna dan mengikat, sedagkan surat dibawah tangan memiliki pembuktian yang tingkatanya dibawah akta otentik."

Guna untuk menganalisa apakah risalah lelang merupakan akta otentik atau bukan, pertama tama risalah lelang harus memenuhi syarat sebagai akta otentik yang diatur pada Pasal 1868 KUHPer, apapun syarat-syarat tersebut yakni:

1. “akta harus dibuat oleh Pejabat Umum.

2. akta itu ditentukan oleh undang-undang;

3. Pejabat Umum yang membuat harus berwenang membuat akta tersebut."19

Jadi apabila risalah lelang tidak memenuhi syarat yang ditentukan oleh Pasal 1868 KUHPer maka risalah lelang tidak dapat dikatan sebagai akta otentik yang memiliki pembuktian yang sempurna. ${ }^{20}$

Guna untuk mendapatkan suatu kebenaran mengenai kekuatan pembuktian risalah lelang, dapat di analisa dengan menggunakan unsur-unsur pada Pasal 1868 KUHPer tersebut yang dianalisa dibawah ini:

1. “Akta harus dibuat oleh Pejabat Umum.

menurut Peraturan Lelang sebuah berita acara lelang atau dapat disebut risalah lelang dibuat oleh Pejabat Lelang sebagaimana diatur oleh Pasal 35 Peraturan Lelang Jo PMK Pelaksanaan Lelang.

2. akta itu ditentukan oleh Undang-Undang

akta tersebut atau risalah lelang dibuat dan diperintahkan oleh UndangUndang dalam hal ini Peraturan Lelang yaitu Pasal 37, Pasal 38 dan Pasal 39.

3. Pejabat Umum yang membuat harus berwenang membuat akta tersebut.

Pejabat Lelang merupakan pejabat umum yang berwenang berdasarkan Peraturan Lelang, Intruksi Lelang dan PMK Pelaksanaan Lelang."

18 Erik, M., Triyanto, T., \& Sesung, R. Op.Cit. h. 13

19 Purnayasa, A. T. (2018). "Akibat Hukum Terdegradasinya Akta Notaris yang Tidak Memenuhi Syarat Pembuatan Akta Otentik". Acta Comitas: Jurnal Hukum Kenotariatan, 3(3), 395409. p. 397-398

20 Tjukup, I. K., Layang, I. W. B. S., Martana, N. A., Markeling, I. K., Dananjaya, N. S., Putra, I. P. R. A., ... \& Tribuana, P. A. R. (2016). "Akta Notaris (Akta Otentik) Sebagai Alat Bukti Dalam Peristiwa Hukum Perdata”. Acta Comitas: Jurnal Hukum Kenotariatan, 1(2). 180-188 p. 185 
Berdasarkan unsur-unsur tersebut telah dipenuhi oleh risalah lelang jadi dapat dikatakan risalah tentang hasil pelelangan merupakan akta otentik yang memiliki kekuatan sebagai bukti yang sempurna ditentukan oleh Pasal 1870 KUHPer.

Namun, menurut Pasal 1969 KUHPer suatu akta otentik akan turun derajat nya menjadi dibawah tangan apabila suatu akta otentik dibuat berdasarkan yang tidak pada kewenangannya walaupun ia adalah pejabat umum. Artinya "apabila risalah lelang dibuat oleh seorang Notaris yang belum diangkat menjadi Pejabat Lelang Kelas II oleh Menteri Keuangan maka Risalah Lelang itu akan menjadi akta dibawah tangan, bukan lagi menjadi akta otentik yang sempurkan kekuatan hukum pembuktianya."

Jadi kekuatan pembuktian risalah lelang menurut Pasal 1868 KUHPer haruslah memenuhi 3 unsur terlebih dahulu yaitu 1) akta itu harus dibuat seorang Pejabat Umum, 2) akta itu ditentukan oleh undang-undang dan 3) Pejabat Umum yang membuat harus berwenang membuat akta tersebut, Risalah lelang telah memenuhi ketiga unsur tersebuk sehingga dapat dikatakan Risalah Lelang itu merupakan akta otentik yang memiliki pembuktian yang sempurna, sepanjang tidak melanggar apa yang ditentukan Pasal 1868 dan Pasal 1869 KUHPer.

\section{Kesimpulan}

Peraturan Lelang merupakan jawaban dari Harmonisasi pengaturan kewenangan Pembuatan Risalah Lelangberdasarkan asas lex specialist derogate legi generalist. Peraturan Lelang sebagai dasar kewenangan membuat Risalah Lelang yaitu terdapat pada Pejabat Lelang bukan pada Notaris. Walaupun Notaris dapat diangkat sebagai Pejabat Lelang Kelas II menurut Pasal 7 Intruksi Lelang jo. PMK Pejabat Lelang Kelas II memiliki wewenang dalam pembuatan Risalah Lelang, namun wewenang itu diberikan dalam kapasitas Notaris sebagai Pejabat Lelang II yang telah diangkat oleh Menteri Keuangan dan bukan kapasitasnya sebagai Notaris.

Kekuatan pembuktian risalah lelang menurut Pasal 1868 KUHPer haruslah memenuhi 3 unsur terlebih dahulu yaitu 1) akta itu harus dibuat seorang Pejabat Umum, 2) akta itu ditentukan oleh undang-undang dan 3) Pejabat Umum yang membuat harus berwenang membuat akta tersebut, Risalah lelang telah memenuhi ketiga unsur tersebut sehingga dapat dikatakan Risalah Lelang itu merupakan akta otentik yang memiliki pembuktian yang sempurna, sepanjang tidak melanggar apa yang ditentukan Pasal 1868 dan Pasal 1869 KUHPer.

\section{Daftar Pustaka}

\section{$\underline{\text { Buku }}$}

Marzuki, M. (2017). Penelitian Hukum: Edisi Revisi. Prenada Media.

Hadjon, P. M., \& Djamiati, T. S. (2014). Argumentasi hukum. Gadjah Mada University Press. 
Soerjono Soekanto, (2012), Pengantar Penelitian Hukum. , Jakarta, Universitas Indonesia Press

Harahap, M. Y. (2007). Ruang Lingkup Permasalahan Eksekusi Bidang Perdata, cet. 3.

\section{Jurnal Ilmiah}

Erik, M., Triyanto, T., \& Sesung, R. (2018). “Karakteristik Akta Otentik Pada Akta Risalah Lelang". Jatiswara, 33(2). 1-20.

Faisal, M. (2014). “Upaya Perlindungan Hukum Pemenang Lelang Sebagai Pembeli Beritikad Baik Terhadap Putusan Re-Eksekusi". Jurnal Hukum \& Pembangunan. 44(1). 83-101.

Haris, M. (2018). "Kewenangan Notaris sebagai Pejabat Lelang Kelas II dalam Memberikan Penyuluhan Hukum atas Akta Risalah Lelang yang Dibuatnya". Syariah: Jurnal Hukum dan Pemikiran, 17(1). 53-63.

Jody Bagus, W. I. W. (2019). “Tinjauan Yuridis Terkait Pendaftaran Hak Tanggungan Secara Elektronik". Jurnal Acta Comitas : Jurnal Hukum Kenotariatan. 5(1). 79-88.

Kusumaningrat, I. D. G. A. "Perlindungan Hukum Bagi Kreditor Terhadap Hapusnya Hak Atas Tanah yang Dibebani Hak Tanggungan". Acta Comitas: Jurnal Hukum Kenotariatan, 4(2), 251-260.

Marziah, A., Rahayu, S. W., \& Jauhari, I. (2019). “Pembuktian Risalah Lelang Bagi Pemenang Eksekusi Hak Tanggungan". Jurnal IUS Kajian Hukum dan Keadilan, 7(2), 225-236.

Rafly R. P., Johny L., \& Neni K. (2018) “Kewenangan Pemerintah Desa Dalam Peningkatan Perekonomian Di Desa Mahangiang Kecamatan Tagulandang Kabupatenkepulauan Sitaro." Eksekutif Jurnal Jurusan Ilmu Pengetahuan1, (1) 1-10

Sasongko, T. I. (2018). “Kewenangan Notaris Dalam Pembuatan Akta Risalah Lelang Pasca Berlakunya Peraturan Menteri Keuangan Nomor 90/PMK. 06/2016 Tentang Pedoman Pelaksanaan Lelang Dengan Penawaran Secara Tertulis Tanpa Kehadiran Peserta Lelang Melaui Internet". Lex Renaissance, 3(1), 206-225.

Satrya, H. (2017) "Penjualan Lelang Barang Jaminan Hak Tanggungan Menurut Perspektif Hukum Islam." Jurnal Repertorium IV (1) 52-60

Sonbai, A. I. K. (2019). "Kebijakan Formulasi Pertanggungjawaban Pidana Pengguna Jasa Prostitusi Melalui Media Online". Acta Comitas: Jurnal Hukum Kenotariatan, 4(2), 271-282.

Purnayasa, A. T. (2018). "Akibat Hukum Terdegradasinya Akta Notaris yang Tidak Memenuhi Syarat Pembuatan Akta Otentik". Acta Comitas: Jurnal Hukum Kenotariatan, 3(3), 395-409. 
Tjukup, I. K., Layang, I. W. B. S., Martana, N. A., Markeling, I. K., Dananjaya, N. S., Putra, I. P. R. A., ... \& Tribuana, P. A. R. (2016). “Akta Notaris (Akta Otentik) Sebagai Alat Bukti Dalam Peristiwa Hukum Perdata". Acta Comitas: Jurnal Hukum Kenotariatan, 1(2). 180-188

\section{Peraturan Perundang-undangan}

Vendu Reglement Peraturan Lelang Peraturan Penjualan Di Muka Umum Di Indonesia (Ordonansi 28 Pebruari 1908, S. 1908-189)

Vendu Intructie Instruksi Lelang di Indonesia (Ordonansi 28 Pebruari 1908, S. 1908-190)

Kitab Undang -Undang Hukum Perdata (KUH Perdata) terjemahan Subekti, R, dan R. Tjitrosudibio

Undang-Undang Republik Indonesia Nomor 2 Tahun 2014 Tentang Perubahan Atas Undang-Undang Nomor 30 Tahun 2004 Tentang Jabatan Notaris (Lembaran Negara Republik Indonesia Tahun 2014 Nomor 3 Dan Tambahan Lembaran Negara Republik Indonesia Nomor 5491

Peraturan Menteri Keuangan Republik Indonesia Nomor 175/PMK.06/2010 tentang Pejabat Lelang Kelas II

Peraturan Menteri Keuangan Republik Indonesia Nomor 27/PMK.06/2016 Tentang Petunjuk Pelaksana Lelang 